\title{
Enhancing sickle cell anemia/sickle cell disease genetic understanding through simulation: A descriptive pilot study
}

\author{
Leighsa Sharoff * \\ School of Nursing, Hunter College, New York, NY, United States
}

Received: March 27, 2015

Accepted: June 1, 2015

Online Published: June 16, 2015

DOI: $10.5430 /$ jnep.v5n9p39

URL: http://dx.doi.org/10.5430/jnep.v5n9p39

\begin{abstract}
Objective: Post-test pilot descriptive study of the genetic component of a simulation scenario addressing sickle cell anemia/sickle cell disease exploring students' and nurse educators' perceived genetic knowledge. Background: Genetic/genomic knowledge has radically changed the way health care is provided. Augmenting this newly required competency into constrained nursing curricula is a challenge. Simulation prepares students for real-world experiences and as we enter the genetic/genomic era, simulation has an obvious role in expanding and developing these competencies.

Methods: Post-test perceptions of genetic knowledge among nursing students and nurse educators following a genetic-based simulation experience.

Results: Thirty-one junior, thirty-one senior nursing students and eight clinical nurse educators agreed that their understanding of the genetic component improved.

Conclusions: Integrating a genetic component into simulation was an effective educational format to further enhance the genetic knowledge of both students and facilitators. The pilot findings support integrating a genetic component into simulation to further enhance the perceived genetic knowledge of both students and nurse educators. Based on the findings, further research with a pre/post survey will be utilized to continue to explore integrating a genetic component into a simulation experience. This article presents utilizing simulation as a novel contemporary hands-on educational experience designed on sickle cell anemia learning for pre-licensed baccalaureate undergraduate students.
\end{abstract}

Key Words: Genetics, Simulation, Nursing Education, Baccalaureate

\section{INTRODUCTION}

Simulation has been used successfully to augment clinical experiences, yet it has not been used as an adjunct to augment the perceived genetic knowledge of nursing students. Simulation is an excellent interactive educational strategy for enhancing students' genetic/genomic knowledge. ${ }^{[1-3]} \mathrm{Ge}-$ netic/genomics knowledge has radically changed the way health care is conceptualized. Genetics is the study of in- heritance and variation while genomics is the study of the structure and function of the genome and its interactions with the environment. The exponential transformation of this science has ripple effects that are just beginning to be felt across the healthcare arena. Sickle cell disease (SCD), which includes sickle cell anemia (SCA), affects millions of people throughout the world and is particularly common among those whose ancestors came from sub-Saharan Africa;

*Correspondence: Leighsa Sharoff; Email: 1sharoff@hunter.cuny.edu; Address: School of Nursing, Hunter College, New York, NY, United States. 
Spanish-speaking regions in the Western Hemisphere (South America, the Caribbean, and Central America); Saudi Arabia; India; and Mediterranean countries such as Turkey, Greece, and Italy. ${ }^{[4]}$ In addition, SCD is also present in Portuguese, Spanish, French Corsicans, Sardinians, Sicilians, and Cypriots. SCD also appears in Middle Eastern countries and Asia. ${ }^{[5]}$ Population migration has spread these diseases to most countries worldwide. ${ }^{[6]}$ Over 300,000 babies with severe haemoglobin disorders are born each year. ${ }^{[6]}$ Nurses are required to be adept at translating scientific evidence relating to genetics/genomics in the practice setting by actively participating in the care and education of patients. Nurses need to be aware of genetic conditions and the implications to nursing practice. ${ }^{[7]}$ Nurse educators not only need to educate themselves on genetic literacy, but with already constrained nursing curricula, must also be innovative and creative in how to enhance their students' genetic knowledge. ${ }^{[8]}$ As SCD is becoming more common in healthcare, nurses should have the basic knowledge and skills to deliver competent personcentered care and support the patient and family through-out their life stages. ${ }^{[9]}$ The changing arena of using genetics to determine screening, diagnosis and treatment in all common diseases that will be the mainstay of everyday nursing care and nurses need to be knowledgeable of its impact on practice.

\subsection{Purpose}

The purpose of this article is to discuss the utilization of a simulated hospitalized patient with sickle cell anemia (SCA) requiring patient care and genetic education, immersing pre-licensure baccalaureate undergraduate students in a realistic clinical situation, promoting critical thinking and patient education while enhancing students' perceived genetic knowledge. A post-test pilot descriptive evaluation of the genetic component of the simulation scenario addressing perceived genetic knowledge of students' and instructors' is presented. Thus, discussing how genetics/genomics can be taught through simulation; how a genetics scenario was used and adapted to meet the needs of junior and senior nursing students and examine these students' perceptions of their genetic/genomic knowledge post the simulation experience will be discussed.

\subsection{Literature review}

Simulation has become a mainstay of curricular design for augmentation of clinical learning and experiences. Nursing programs complement clinical learning sites, as well as didactic content, with campus simulation scenarios to provide experiential learning opportunities for learners to apply theoretical knowledge. ${ }^{[10]}$ Integrating a genetic component into a simulation provides another venue for active educational learning. There is very little literature addressing how to integrate genetic education into healthcare curriculum using simulation. ${ }^{[11,12]}$ The development of critical thinking, skill performance and medical condition comprehension, with computer-based learning/simulation whereby interactive patient scenarios are integrated in the learning process, is an effective teaching strategy. ${ }^{[10,13]}$ This article presents utilizing simulation as a novel contemporary hands-on educational experience designed on SCA learning for pre-licensed baccalaureate undergraduate students.

\subsubsection{Genetics}

With the sequencing of the human genome as part of the $\mathrm{Hu}$ man Genome Project (HGP), there has been an exponential transformation in medicine, nursing and health care delivery. ${ }^{[14]}$ It is widely recognized that nurses require more than a basic understanding of human genetics, including the rudimentary principles of gene action and inheritance patterns. The genetics education framework defined genetic literacy for nurse education and was recently updated, since being developed in the United Kingdom in 2003, to reflect advances in genomic technology, research and implications for integrating genetics into practice. ${ }^{[15,16]}$ National and international countries are working to enhance genetics/genomics in nursing education and practice with the goal of promoting nurses' knowledge base promoting safe and effective care and competent practice. ${ }^{[17]}$ To address learning needs of clinicians and nursing students, the National Coalition for Health Professional Education in Genetics developed specific core competencies for the integration of genetics into healthcare education. ${ }^{[18]}$ Core competencies for the integration of genetics/genomics into education for healthcare professionals from all disciplines describe the necessary minimum knowledge and skills. ${ }^{[18,19]}$ These core competencies provide the foundational structure for the educational preparedness of nurses and nursing students. Genetics education for all nurses, including pre-licensure students, will provide essential information leading to an informed workforce, able to understand and explain genetic concepts and therapeutics, provide patient education, make genetic referrals and participate in inter-professional teams, with professionals such as genetic researchers and genetic counselors. ${ }^{[20]}$ Integrating genetics throughout nursing curricula (pre-licensure and advanced degree students) is needed to help prepare the next generation of nurses to use genetics and genomic information for optimal patient care, making genetics and genomics relevant to clinical practice and simulation is a way to do this. ${ }^{[21-23]}$ For example, teaching nursing students about the implications of newborn screening and screening technologies will assist them in the clinical setting, by enhancing their ability to understand and possibly identify 
treatable conditions in early infancy. ${ }^{[24]}$ Nurses need to be able to identify patients with genetic disorders to advocate for and facilitate their access to services and resources. ${ }^{[25]}$ "Being confident in understanding the science will help the nurse to support an individual or family in understanding their condition or treatment regimen by answering questions or clarifying information that has been provided by other healthcare professional" ${ }^{[26]}(\mathrm{p} .42)$.

It is necessary for nurses to enhance their overall knowledge foundation, skills and attitudes about genetics to prepare for the transformation in healthcare that is already underway. Godino \& Skirton assert that "nurses' knowledge of genetics and genomics is not adequate to enable them to offer appropriate genetic healthcare"[27] (p.181). There is a "large gap" between what nurses actually know and what they need to know in the genetic/genomic age and in the preparation of nurse educators to "close the gap" that is reflected in newly licensed nurses' low genetic knowledge level. ${ }^{[28,29]}$ The depth of genetic/genomic knowledge needed to effectively and efficiently participate in current and future healthcare arena requires nurse educators to be innovative in how that knowledge is translated to nursing students. The success of nursing students in becoming informed healthcare providers, able to participate in the genetic/genomic era, resides with nurse educators providing experiences to integrate these competencies.

\subsubsection{Sickle cell disease (SCD)}

SCD is a group of genetically-based red blood cell conditions (autosomal recessive) in which the gene mutation leads to hemoglobin assuming a sickle shape, promoting vaso-occlusion, leading to acute and chronic vascular inflammation. ${ }^{[30]}$ SCD results from an amino acid substitution of valine for glutamic acid at position 6 of the beta-globin chain. This alteration causes deoxygenated sickle hemoglobin to form polymers that ultimately destroy red cells, thereby producing anemia. ${ }^{[5]}$ SCD affects 90,000 to 100,000 Americans, approximately 1 in 500 African Americans and practically $5 \%$ of the world's population carries trait genes for haemoglobin disorders, mainly, SCD and thalassaemia. ${ }^{[4]}$ The hallmark manifestation of pain is related to the vasoocclusion, reperfusion injury and hypoxemia. ${ }^{[31]}$ Hospital admittance to medical-surgical nursing units is seeing an increase in inpatients with SCD and need to be able to appropriately manage their care. ${ }^{[32]}$

\subsubsection{Simulation}

High-fidelity human patient simulation (HFS) provides an environment that as realistically as possible reflects a clinical setting, offering students an opportunity to enhance diverse learning needs. Simulation has proven to be an effective teaching strategy encouraging active learning, yet simulation integrating genetics concepts is limited. ${ }^{[33]}$ Evaluation of an augmented curriculum in genetics using lecture and standardized patient encounters led to significant improvement in knowledge and perceived understanding of genetics for physician assistant students. ${ }^{[11]}$ One study utilized a high-fidelity crucial conversation simulation with a prenatal genetic counseling scenario requiring disclosure of an abnormal amniocentesis result and discussion of pregnancy management options for senior genetic counseling students and medical residents. The researchers demonstrated that HFS is an effective learning tool to expose students to rare learning opportunities for genetic trainees. ${ }^{[12]}$ Other formats have utilized internet-based educational programs to enhance genetic education with positive outcomes. ${ }^{[34,35]}$ Though simulation has been shown to be an effective strategy in the development of critical thinking, skill performance and learner satisfaction, there is an obvious gap in evaluating simulation use to enhance nursing students' perceived genetic knowledge. ${ }^{[33,36]}$

\section{METHOD}

Based on the limited literature available in the area of genetics and simulation use, a sickle cell anemia/sickle cell disease case scenario (SCA/SCD; simulated patient: Mr. Tony Wallace) was adapted from the National League of Nursing, with the aim of enhancing students' experience with perceived genetic knowledge, patient education and care. ${ }^{[37]}$ The Simulation Coordinator developed and incorporated pre-briefing preparatory material which students and instructors receive prior to their scheduled simulation. ${ }^{[38]}$ The pre-briefing preparatory materials provide an overview of the simulation case scenario, including but not limited to: current and recent medical history; patient family history; clinical signs immediately visible; patient data (date of birth; height/weight; religion; allergies); pending diagnostic studies; stat lab results and standing orders which includes medications. In addition, the preparatory material provides specific learning objectives, such as: demonstrates appropriate nursing interventions in a patient with SCA/SCD and demonstrates appropriate knowledge in providing family members with genetic information pertaining to SCA/SCD. ${ }^{[36]}$ Finally, the pre-briefing preparatory material contains several YouTube videos that were selected based on their content to this specific simulation scenario. ${ }^{[38]}$ Integrating specific videos from YouTube allows students to develop a deeper appreciation of the subject matter and presents an opportunity for experiential learning, further exposing learners to new insights and skills. ${ }^{[39]}$ Videos on SCD; the genetics of SCD; sickle cell gene combinations and a 
patients' journey were provided.

Instructor preparatory material was significantly more detailed, providing additional information on pathophysiologic mechanisms, complications, treatment options, nursing diagnosis', images and patient education material. ${ }^{[38]}$ The design of pre-briefing preparatory materials must enhance students' knowledge base, skills acquisition, required competencies and learning outcomes. ${ }^{[40]}$ Learning outcomes, skill performance, critical thinking, self-confidence, and communicative abilities all constitute the construct of simulation success in enhancing students' abilities. ${ }^{[41,42]}$

The SCA/SCD scenario was used for two groups of students (juniors and seniors levels) with some adaption in the scenario to meet the needs of both student groups. Senior students, scheduled for a medical-surgical simulation, received the scenario as written with no change in the age of the simulated patient case. Junior students, who were scheduled for a pediatric simulation experience, received the simulated patient case but with a specific age of 3 years old, including appropriate age-related changes in medications, doses and laboratory data. A pediatric nurse practitioner, with extensive knowledge of SCA/SCD, provided expert content assistance with revising the scenario as well as assisting with survey development.

\subsection{Simulated scenarios utilized}

The two SCD scenarios had significant differences, ranging from age of the simulated patient to the main focus of the experience. The junior level pediatric scenario had a newly diagnosed 3 year old being admitted to the hospital for the first time. As with autosomal recessive conditions, neither parent expressed the condition though both were genetic carriers. The case scenario information given to the students in the pre-briefing preparatory material included: Tony Wallace is a 3-year-old African-American male admitted for first episode of Sickle Cell Anemia/Vaso-occlusive pain episode. Mother and Father present at bedside. Parents have 2 other children (13 years old female; 9 years old male). Neither child has been diagnosed with SCA. Mothers' mother (maternal grandmother) had SCD. Father denies any family member with active condition and no one was ever tested for SCD trait. He is complaining of severe pain in his hands and feet. $\mathrm{He}$ is febrile $38.3^{\circ} \mathrm{C}(101 \mathrm{~F})$. Upon examination, the nurse notes that the palms of the hands and the soles of the feet are red and edematous with a moderate rash. Parents are extremely anxious and do not understand why their child is so sick. Parents are from the Caribbean Islands. All of their children were born in the U.S.A.

Instructors received this additional information: This case presents a patient with sickle cell anemia (SCA/HbSS) being admitted with an initial acute painful episode. Patients' parents do not understand the genetic relationship and are asking the nurse to explain what is happening. The students will be expected to perform a general assessment, perform pain assessment and care. The students will be expected to provide genetic education for the patient and his family on SCA/SCD. In addition, students will be expected to understand the complications of SCD, such as Hand-Foot Syndrome. As genetics and genomics are a required competency, knowing how to explain this condition will help the students gain a deeper understanding of this requirement.

\subsection{Senior level students}

The case scenario information given to the senior level students in the pre-briefing preparatory material included: Tony Wallace is a 24 year old African-American male with known SCA/SCD who was admitted five day ago with an acute pain episode. Mr. Wallace is asking questions related to his condition. He has been treated with morphine, Toradol, Benadryl and Phenergen. He has a peripheral IV with normal saline infusing at $120 \mathrm{ml} /$ hour and a patient-controlled analgesia delivery system (PCA) with morphine running at $2 \mathrm{mg} / \mathrm{hour}$. This morning Tony seems very tired and refuses to get out of bed. He has not been using incentive spirometry because he doesn't feel that it helps him. Mr. Wallace continues to complain about leg, arm and joint pain and doesn't understand why he keeps getting sick. This morning he also claims to have chest pain which he rates as a 9 out of 10 pain scale. $\mathrm{He}$ is requesting Toradol as often as he can have it and has requested an increase in the PCA bolus dose too. Right now, Tony is currently sleeping and snoring at times. His mother wants to talk to the nurse about SCD. ${ }^{[37]}$

Instructors received this additional information: This case presents a patient with sickle cell anemia (SCA/Hbss). The patient is being admitted with an acute pain episode as he has had difficulty controlling his pain and has asked that someone explain why he is experiencing this. He unexpectedly develops a fever of $38.4^{\circ} \mathrm{C}(101.2 \mathrm{~F})$ orally and hypoxemia on day 3 of his hospitalization, with an oxygen saturation $<92 \%$. The students will be expected to perform a general assessment, perform pain assessment and care and recognize a deteriorating patient requiring nursing and medical interventions. The students will be expected to provide genetic education for the patient and his family on SCA/SCD. In addition, students will be expected to understand and explain the complications of SCD, such as Acute Chest Syndrome. As genetics and genomics are a required competency, knowing how to explain this condition will help the students gain a deeper understanding of this requirement. 


\subsection{Design/participants}

A descriptive post-test design was employed to evaluate the perceived genetic knowledge among nursing students and nurse educators, in a large diverse urban school of nursing (SON), following a genetic-based simulation experience. Students' genetic level of perceived knowledge post the simulation experience was explored. All study procedures received exempt institutional review board (IRB) status during the Spring 2014 semester. Among the 100 juniors taking a pediatric clinical course and 100 seniors taking a medical-surgical clinical course, a random choosing led to eight clinical nursing groups (four in junior $[n=31] /$ four in senior $[n=31]$ ) and eight clinical nurse educators $(1$ male/7 females $[\mathrm{n}=8])$ participating, as shown in Table 1. All simulations and data collection were held at the SON's simulation center. A simulation experience is a required part of the clinical practicum. Every clinical group is assigned to one simulation day with their clinical instructor. To coincide with students' didactic course content and educational level, different scenarios are utilized to provide for a variety of experiences and were randomly assigned to clinical groups. Simulation scenarios are leveled through nursing curricula to ensure a logical progression of skill and knowledge development while exposing students to increasingly complex simulation scenarios in order to progressively develop clinical judgment and clinical reasoning. ${ }^{[38]}$

Table 1. Demographic data

\begin{tabular}{lll}
\hline Clinical Groups & Number of Participants & Gender \\
\hline 4 Junior Level Clinicals & Junior Level $(\mathrm{n}=31)$ & 27 females $/ 4$ males \\
4 Nurse Educators & $\mathrm{n}=4$ & 3 females 1 male \\
4 Senior Level Clinicals & Senior Level $(\mathrm{n}=31)$ & 29 females $/ 2$ males \\
4 Nurse Educators & $\mathrm{n}=4$ & 4 females \\
\hline
\end{tabular}

\subsection{Assessment of perceived genetic knowledge}

With few instruments available to assess student selfperceptions of their genetic knowledge and none exploring their self-perceptions of genetic knowledge after a simulation experience, a six question survey was developed. ${ }^{[43,44]}$ The survey examined students' perceived genetic knowledge after their simulation experience, explored the perceived understanding of the genetic component (SCA/SCD); ability to provide the patient and family with information about SCA/SCD; level of perceived understanding of SCA/SCD appropriate to provide effective and efficient nursing care with appropriate nursing interventions; critical thinking skills about providing genetic information to a patient; clinical judgment about providing genetic information to a patient and asked if this scenario enhanced their overall ability to integrate genetics into their knowledge base of nursing and nursing care. Participants could respond to each question by noting "Strongly agree", "Agree", "Disagree" or "Strongly Disagree". Additionally, participants were asked to respond to "How can this simulation integrating genetics be improved to further enhance your overall knowledge?"

The SON involved in this study adapted Tanner's Clinical Judgment Model as its simulation theoretical framework. Tanner's model, derived from a synthesis of the literature on clinical judgment, is a rubric that defines stages or levels of clinical judgment development. ${ }^{[45]}$ Tanner's Clinical Judgment Model analyzed and described the complex model of clinical judgment, defining clinical judgment as "an inter- pretation or conclusion about a patient's needs, concerns or health problems, and/or the decision to take action (or not), to use or modify standard approaches, or to improve ones' as deemed appropriate by the patient's response"[45](p.204). According to Tanner's model, the nurse's perception of any situation is influenced by the context and strongly shaped by the nurse's practical experience; it is also rooted in the nurse's theoretical knowledge, ethical perspectives and relationship with the patient. This frame allows for some unique differences in the ways nurses may notice patient situations to set the cycle in motion. Clinical judgment is demonstrated through a variety of reasoning processes, including analytic, which is predominant with students; intuitive, which is based in practical experience and which students generally lack; and narrative, or the learning that occurs from nurses and students telling their stories. ${ }^{[45,46]}$ Clinical judgment refers to the ways in which nurses come to understand the problems, issues, or concerns of clients/patients, to attend to salient information and to respond in concerned and involved ways. ${ }^{[47]}$ Reflection is the catalyst for clinical learning, allowing students to sort out their learning through an exploratory process. Tanner's Clinical Judgment Model strongly links clinical learning, one of the outcomes of clinical judgment, to the nurse's background, implying that the nurse is continually learning and developing with each patient encounter. In this way, reflecting on clinical judgments foster development and experience. The four phases to this model (Noticing, Interpreting, Responding, and Reflecting) correlate to clinical judgment as it relates to the multidimensional complexity of 
patient care. ${ }^{[45]}$ The survey, being designed around the constructs of this model, was initially reviewed by the Assistant Dean of Research at the SON and the University's Office of Assessment, an educational resource center for faculty. Both sources were knowledgeable of Tanner's model and its application to the SON simulation process.

The simulation technologist, after reading an IRB-approved script, handed out and collected the survey. The simulation technologist had no conflict of interest or potential for bias in participants' responses, thus no form of coercion occurred. The script briefly described the purpose of the study and addressed key IRB aspects, including: informing participants that participation was not mandatory and refusal to complete the survey would not affect their standing in the course or the SON; completion of the survey deemed consent; no personal identifiers were collected from the participants; only gender was requested for demographic data and completion of the survey should take approximately 5 minutes. The researcher was not present for any of the simulation experiences nor had any administrative responsibilities regarding the instructors, eliminating coercion possibilities there as well. Ethical consideration for all participants was at the forefront of this study. The researcher did not engage in any discussion on this study with any student enrolled in the SON nor with any instructor.

\subsection{Statistical analysis}

Data were coded and entered into an SPSS database. Descriptive statistics including frequencies and percentages were utilized for demographic data while contingency table analysis was used to summarize the categorical perception data. Per question response rate was $100 \%$. Participant comments were analyzed, along with quantitative results, further informing the researcher on the perceived genetic knowledge post the simulation experience. Qualitative data analysis was analyzed according to coding themes, with new codes developed that emerged from the investigator's content analysis of the transcripts. Inter-rater reliability was maintained by working with the Assistant Dean of Research.

\section{RESULTS}

\subsection{Student}

Thirty-one junior nursing students (27 females/4 males) taking a required pediatric clinical course and thirty-one senior nursing students (29 females/2 males) taking a required medical-surgical clinical course participated in this study. In addition, eight clinical nurse educators ( 1 male/7 females [ $\mathrm{n}$ $=8$ ]) also participated. All participants completed the entire survey with no data missing.

Table 2. Student survey with descriptive statistics

\begin{tabular}{|c|c|c|c|c|}
\hline \multirow{2}{*}{$\begin{array}{l}\text { Assessment of Genetic Knowledge After Simulation } \\
\text { Student Results }\end{array}$} & n (SD) & n (SD) & n (SD) & n (SD) \\
\hline & Strongly agree & Agree & Disagree & Strongly disagree \\
\hline $\begin{array}{l}\text { Your understanding of the genetic component of SCA/SCD } \\
\text { improved after this simulation experience? }\end{array}$ & $\begin{array}{l}24(.495) \\
j=9 \\
s=15\end{array}$ & $\begin{array}{l}36(.500) \\
j=21 \\
s=15\end{array}$ & $\begin{array}{l}1(-) \\
j=1\end{array}$ & $\begin{array}{l}1(1) \\
\mathrm{s}=1\end{array}$ \\
\hline $\begin{array}{l}\text { Your ability to provide the patient and family with } \\
\text { information pertaining to sickle cell anemia/sickle cell } \\
\text { disease (SCA/SCD) was satisfactory? }\end{array}$ & $\begin{array}{l}11(.522) \\
j=5 \\
s=6\end{array}$ & $\begin{array}{l}49(.504) \\
j=26 \\
s=23\end{array}$ & $\begin{array}{l}2(-) \\
s=2\end{array}$ & \\
\hline $\begin{array}{l}\text { Your level of understanding of SCA/SCD was appropriate } \\
\text { to provide effective and efficient nursing care with } \\
\text { appropriate nursing interventions? }\end{array}$ & $\begin{array}{l}7(.488) \\
j=2 \\
s=5\end{array}$ & $\begin{array}{l}53(.504) \\
j=28 \\
s=25\end{array}$ & $\begin{array}{l}2(.707) \\
j=1 \\
s=1\end{array}$ & \\
\hline $\begin{array}{l}\text { Your critical thinking skills about providing genetic } \\
\text { information to a patient in this situation have been } \\
\text { improved? }\end{array}$ & $\begin{array}{l}16(4.79) \\
j=5 \\
s=11\end{array}$ & $\begin{array}{l}45(.499) \\
j=26 \\
s=19\end{array}$ & $\begin{array}{l}1(-) \\
\mathrm{s}=1\end{array}$ & \\
\hline $\begin{array}{l}\text { Your clinical judgment about providing genetic information } \\
\text { to a patient in this situation has been improved? }\end{array}$ & $\begin{array}{l}17(.507) \\
\mathrm{j}=7 \\
\mathrm{~s}=10\end{array}$ & $\begin{array}{l}45(.505) \\
j=24 \\
s=21\end{array}$ & & \\
\hline $\begin{array}{l}\text { Did you feel that this scenario enhanced your overall ability } \\
\text { to integrate genetics into your knowledge base of nursing } \\
\text { and nursing care? }\end{array}$ & $\begin{array}{l}15(.507) \\
\mathrm{j}=6 \\
\mathrm{~s}=9\end{array}$ & $\begin{array}{l}45(.505) \\
j=24 \\
s=21\end{array}$ & $\begin{array}{l}2(.707) \\
j=1 \\
s=1\end{array}$ & \\
\hline
\end{tabular}

Note. $\mathrm{n}=31$ Junior nursing students (j), $\mathrm{n}=31$ Senior nursing students (s).

Majority of students (88.6\%) agreed their understanding of the genetic component of SCA/SCD improved after the simulation. This was the only question where one student disagreed and one strongly disagreed. These two participants 
did not provide any rationale as to why they perceived that their understanding of the genetic component of SCA/SCD did not improve after the simulation. No other question had any students who strongly disagreed. Forty-nine students agreed their ability to provide the patient and family with information pertaining to SCA/SCD was satisfactory after the simulation $(\mathrm{SD}=.504)$. Majority of students $(\mathrm{n}=53$; $\mathrm{SD}$ $=.504$ ) felt their level of understanding of SCA/SCD was appropriate to provide effective and efficient nursing care with appropriate nursing interventions. Forty-five students agreed their critical thinking skills $(\mathrm{SD}=.499)$ and clinical judgment $(\mathrm{SD}=.505)$ about providing genetic information improved with this simulation. Finally, 45 students (SD = $.505)$ felt this scenario enhanced their overall ability to integrate genetics into their knowledge base and nursing care. Comparatively, there was minimal differences noted between junior (pediatric clinical) and senior (adult clinical) to each survey question, as shown in Table 2.

Student comments described how they felt their genetic knowledge improved: "know my genetic information better now", "genetics is important to know about for assessing the patient and for future patient education", "felt I understood the genetic components now... it was helpful to think about how to talk to patient about it" and "the simulation let students actually feel the responsibility of being a RN".

\subsection{Instructor}

Eight clinical nurse educators agreed to complete the survey. No educator disagreed or strongly disagreed to any survey questions. Adding a genetic component enhanced the educators' genetic literacy (100\%); 62.5\% agree their ability to provide information pertaining to SCA/SCD improved as did their level of understanding of SCA/SCD. Critical thinking skills and clinical judgment also had $62.5 \%$ agreement the simulation experience enhanced their overall genetic literacy. Finally all felt the simulation enhanced their overall ability to integrate genetics into their knowledge base. Comments from instructors related to their need to know more about genetics, "I feel like I still need more help with genetics but this was a good introduction" and "excellent way to integrate this new competency".

\section{Discussion}

Including a genetic component during a simulation experience enhances students' and nurse educators' perception of genetic knowledge base. Neither junior nor senior students received a stand-alone genetics course since the assumption at this SON, at the time of this study, was that genetics/genomics was integrated into the curriculum. This descriptive pilot revealed that including a genetic aspect to a

Published by Sciedu Press simulation experience was not only feasible but was viewed positively by both students and educators. Creating one primary scenario that was adapted based on the student's level (junior versus senior) could be successfully used to meet learning objectives and outcomes. All participants agreed that their perceived genetic knowledge improved after the simulation.

It is necessary for nurse educators to provide a variety of learning strategies, engaging students intellectually as well as motivationally. The ethical, legal, social and psychological implications regarding genetic education and the impact it can have on the patient/family must be clearly expressed to students, ensuring they understand the need to provide appropriate information and competent care. ${ }^{[48]}$ Simulation offers a creative and innovative learning strategy to enhance the perceived genetic knowledge of nursing students. Simulation provides for an innovative and dynamic learner-centered learning strategy to enrich students' and faculty's perceived genetic knowledge. ${ }^{[38]}$ In conjunction with other teaching strategies (lecture/discussion), simulation provides an opportunity for students to practice communication skills, whereby talking to patients about genetics-related topics will be more natural and students' confidence will be enhanced. ${ }^{[4]}$ Simulated/standardized patients can assist students in learning to discuss a variety of genetic-based conditions, "helping them to improve their genetics history-taking, and allow for exploration of the ethical, legal, and social issues inherent in genetics counseling"[49] (p.129).

This pilot study's findings support the use of simulation as an "effective format as an active learning strategy throughout undergraduate nursing curriculum". ${ }^{[50]}$ With new knowledge come new responsibilities reflected by the genetic required competencies. Implementing these competencies into an already constrained curriculum requires nurse educators to establish new integrative teaching formats. ${ }^{[38]}$ It is important for all nurses to have a basic understanding of the implications of genetically-based conditions. ${ }^{[26]}$ Nurses and their patients will benefit when this new competency and its knowledge is integrated into practice and services to help promote early intervention as evidenced by early identification, diagnosis and implications. ${ }^{[51]}$ Simulation prepares students for real-world experiences and being healthcare providers during the genetic/genomic era, simulation has an obvious role in expanding and developing these competencies, in a safe and friendly learner-centered environment. By integrating genetics into a simulation, facilitators' perceived genetic literacy knowledge base will improve, thus furthering their confidence and ability to assist students to meet these new competencies. As the nurses' confidence increases with their genetic/genomic knowledge and skill, they will 
be better equipped to provide their patients with essential genetic/genomic information and resources.

\section{Limitations}

Due to the limited number of participants within only one SON, even though random sampling increases the statistical validity of the sample, results cannot be generalized to other schools. Utilizing a post-test only was not a feasible design for significantly measuring knowledge. However, this pilot did demonstrate that simulation is an innovative way to incorporate genetic information. Replication of this evaluation would include both a pre and post-test to affirm these findings, a comparison group, as well as a knowledge questionnaire to evaluate actual (versus perceived) knowledge gain. Genetics education is very important, but educators need to move away from teaching simply about the traditional dominantly inherited rare diseases. This is another limitation. However, all nurses and nursing students should have basic knowledge of genetically-based conditions as well as the more complex genetic issues. Using simulation as a learning method can assist in this context but needs evaluating with more genetically-based scenarios. Additionally, a significant limitation was the absence of a control group. Finally, a possible bias existed between the students and the design of the simulation experience, whereby some instructors may have a strong genetics/genomics background while others may be limited.

\section{Conclusion}

Pilot findings support integrating a genetic component into simulation to further enhance the perceived genetic knowledge of both students and facilitators. The need for genetic/genomic knowledge for nurses has exponentially increased over the last decade; however, the integration of this required competency into nursing curricula has not kept the same pace. Studies have shown that pre-licensure nursing students and advanced practice nursing students lack genetic knowledge and have a significant gap in their perceived knowledge base. ${ }^{[43,44]}$ In addition, faculty members' perceived genetic knowledge base also is frequently inadequate. ${ }^{[52]}$ Nurses will be faced with daily challenges involving genetics and will be required to keep themselves apprised of the changes in this rapidly advancing field.

SCD is a global public health issue. ${ }^{[5]}$ The primary care of patients with SCD is a multi-disciplinary team approach, with nurses providing essential care. The health burden of haemoglobin disorders can be effectively reduced through

\section{REFERENCES}

[1] Weaver A. High-fidelity patient simulation in nursing education: An integrative review. Nursing Education Perspectives. 2011; 32(1): management and prevention programmes ${ }^{[6]}$ with health monitoring and prevention of complications essential for patient survival. ${ }^{[5]}$ It is important to note that nurses in a general setting would not be expected to discuss the implications of a sickle cell disease diagnosis or cystic fibrosis diagnosis, or about carrier testing, Downs Syndrome or cleft palate, this would all be within a specialist service, as the care of patients with these genetically-based conditions require the expertise of medical sub-specialists at times. ${ }^{[5]}$ However, all nurses are expected to be able to participate in the care of these patients and provide effective and efficient health care. Nurses should be able to integrate the basic core competencies of knowledge, skills and attitudes regarding genetics into their practice. ${ }^{[18]}$ For more advanced involvement, such as providing genetic counseling, facilitating genetic testing and interpreting genetic test results and laboratory reports a nurse would need an advanced practice degree. ${ }^{[53]}$ Nurses in all clinical practice settings are required to have enough genetic knowledge to help families understand why genetic testing may be necessary, provide appropriate referrals and explanations of genetic conditions and assure families are informed throughout the process. ${ }^{[25,26]}$ Providing students with opportunities to demonstrate their ability to apply their knowledge of genetics and genomics and convey that information as patient education is an essential teaching strategy. ${ }^{[54]}$

Future research studies can explore other important genetic counseling issues such as how comfortable the nurse is in explaining the genetic inheritance pattern of cystic fibrosis to parents who have mutations in their CFTR gene, or the inter-disciplinary care of a nurse and a genetic counselor in evaluating an infant with a midline cleft palate or the care of a newborn with Down Syndrome. Simulation technology can improve "engagement with learners, provide educational opportunities outside the traditional lecture room settings, and can foster the wider dissemination of information" ${ }^{21]}(\mathrm{p} .16)$. Simulation scenarios are only limited by the nurse educators' imagination and creativity.

\section{ACKNOWLEDGEMENTS}

The author would like to thank all those who participated and Mr. Marvin Sanon for assisting with the data collection. The author received no extramural funding and no commercial financial support in this research. The author declares that there is no conflict of interest statement.

\section{CONFLICTS OF INTEREST DisClosure}

The author declares that there is no conflict of interest.

37-40. http://dx.doi.org/10.5480/1536-5026-32.1.37

[2] McCaughey CS, Traynor MK. The role of simulation in nurse education. Nurse Education Today. 2010; 30(8): 827-832. PMid:20483188 
http://dx.doi.org/10.1016/j.nedt.2010.03.005

[3] Tonkin E, Calzone K, Jenkins J, et al. Genomic education resources for nursing faculty. Journal of Nursing Scholarship. 2011; 43(4): 330-340. PMid:22034967 http://dx.doi.org/10.1111/j.154 7-5069.2011.01415.x

[4] Center for Disease and Prevention (n.d.). Sickle Cell Disease. 2011. Available from: http://www.cdc.gov/NCBDDD/sicklecell/da ta.html

[5] Sickle Cell Disease Association of America (SCDAA). (n.d.). Available from: http://sicklecelldisease.org/index.cfm?pa ge=home

[6] World Health Organization. Sickle-cell disease and other haemoglobin disorders. 2011. Available from: http: //www. who.int/mediacentre/factsheets/fs308/en/

[7] Burke S, Bennett C, Bedward J, et al. The experiences and preferences of people receiving genetic information from healthcare professionals. NHS National Genetics Education and Development Centre. Birmingham. 2007. Available from http://www.geneticseducation.nhs.uk/downloads/006 6Patients_experiences_report_Sept_2007.pdf

[8] Sharoff L. Genetics and Genomics Integration into Undergraduate Nursing Education. Journal of Nursing Education and Practice. 2015; 5(4): 13-18. http://dx.doi.org/10.5430/jnep.v5n4p13

[9] Kirk M, Marshallsay M. Providing nursing care and support to individuals and families with genetic/genomic healthcare needs. Nursing Standard. 2013; 28(16-18): 39-46. PMid:24345152 http: //dx.doi.org/10.7748/ns2013.12.28.16.39.e7470

[10] McIntosh C, Thomas C, Allen R, et al. Using a Combination of Teaching and Learning Strategies and Standardized Patient for a Successful Autism Simulation. Clinical Simulation in Nursing. 2015; 11(3): e143-152. http://dx.doi.org/10.1016/j.ecns. 2014 .11 .008

[11] LeLacheur S, Straker H, Macri C. Evaluation of a genetics curriculum for physician assistant students. The Journal of Physician Assistant Education. 2007; 18(2): 44-46. http://dx.doi.org/10.1097/0 1367895-200718020-00008

[12] Holt R, Tofil N, Hurst C, et al. Utilizing high-fidelity crucial conversion simulation in genetic counseling training. American Journal of Medical Genetics. 2013; 161(6): 1273-1277. PMid:23633180 http://dx.doi.org/10.1002/ajmg.a.35952

[13] Weatherspoon D, Phillips K, Wyatt T. Effect of Electronic Interactive Simulation on Senior Bachelor of Science in Nursing Students' Critical Thinking and Clinical Judgment Skills. Clinical Simulation in Nursing. 2015; 11(2): e126-133. http://dx.doi.org/10.10 $16 /$ j.ecns . 2014.11.006

[14] National Institute of Health. National Human Genome Research Institute (NHGRI). 2003. Available from: http: //www . genome.gov /10001772

[15] Kirk M. Introduction to genetics and genomics: A revised framework for nurses. Nursing Standard. 2013; 28(8): 37-41. PMid:24147714 http://dx.doi.org/10.7748/ns2013.10.28.8.37.e7466

[16] Kirk M, McDonald K, Anstey S, et al. Fit for Practice in the Genetics Era: A Competence Based Education Framework for Nurses, Midwives and Health Visitors. University of Glamorgan, Pontypridd. 2003.

[17] Kirk M, Calzone K, Arimori N, et al. Genetics-Genomics Competencies and Nursing Regulation, Journal of Nursing Scholarship. 2011; 43(2): 107-116. PMid:21605314 http://dx.doi.org/10.1111 /j.1547-5069.2011.01388.x

[18] National Coalition for Health Professional Education in Genetics. Core Competencies in Genetics Essential for All Health-Care Professionals. 2007. Available from: http://www.nchpeg.org/
[19] Burke S, Kirk M. Genetics education in the nursing profession: Literature review. Journal of Advanced Nursing. 2006; 54(2): 228 237. PMid:16553709 http://dx.doi.org/10.1111/j.1365-2 $648.2006 .03805 . x$

[20] Cashion AK. The importance of genetics education for undergraduate and graduate nursing programs. Journal of Nursing Education. 2009; 48(10): 535-536. PMid:19831335 http://dx.doi.org/10.3928 /01484834-20090918-01

[21] Berger A, Johnson S, Beachy S, et al. Improving genetic education in graduate and continuing health professional education: Workshop Summary Washington, DC: The National Academies Press; 2015.

[22] Calzone K, Cashion A, Feetham S, et al. Nurses transforming health care using genetics and genomics. Nursing Outlook. 2010; 58(1): 26-35. PMid:20113752 http://dx .doi.org/10.1016/j.outlo ok. 2009.05.001

[23] Lea D, Skirton H, Read C, et al. Implications for educating the next generation of nurses on genetics and genomics in the 21 st century. Journal of Nursing Scholarship. 2011; 43(1): 3-12. PMid:21342419 http://dx.doi.org/10.1111/j.1547-5069.2010.01373.x

[24] DeLuca J, Zanni K, Bonhomme N, et al. Implications of newborn screening for nurses. Journal of Nursing Scholarship. 2013; 45(1): 25 33. PMid:23368429 http://dx.doi.org/10.1111/jnu.12005

[25] Prows C, Hopkin R, Barnoy S, et al. An update of childhood genetic disorders. Journal of Nursing Scholarship. 2013; 45(1): 34-42. PMid:23294802 http://dx.doi.org/10.1111/jnu. 12003

[26] Tonkin E, Skirton H. The role of genetic/genomic factors in health, illness and care provision. Nursing Standard. 2013; 28(12): 39-46. PMid:24251514 http://dx.doi.org/10.7748/ns2013.11.28 12.39.e7550

[27] Godino L, Skirton H. A systemic review of nurses' knowledge of genetics. Journal of Nursing Education and Practice. 2012; 2(3): 173-184. http://dx . doi .org/10.5430/jnep.v2n3p173

[28] Collins C, Stiles A. Predictors of student outcomes on perceived knowledge and competence of genetic family history risk assessment. Journal of Professional Nursing. 2011; 27(2): 101107. PMid:21420042 http://dx.doi.org/10.1016/j.profnur s. 2010.09 .007

[29] Williams J, Prows C, Conley Y, et al. Strategies to prepare faculty to integrate genomics into nursing education programs. Journal of Nursing Scholarship. 2011; 43(3): 231-238. http://dx.doi.org /10.1111/j.1547-5069.2011.01401.x

[30] Ballas S, Kesen M, Goldber M, et al. Beyond the definitions of the phenotypic complications of sickle cell disease: An update on management. Scientific World Journals. 2012.

[31] Solomon L. Pain management in adults with sickle cell disease in a medical emergency department. Journal of the National Medical Association. 2010; 102: 1025-1032. PMid:21141290

[32] Jenerette C, Leak A. The role of oncology nurses in the care of adults with sickle cell disease. Clinical Journal of Oncology Nurses. 2013; 16(6): 633-635. PMid:23178356 http://dx.doi.org/10.1188 /12. CJON.633-635

[33] Guhde J. Using online exercises and patient simulation to improve students' clinical decision-making. Nursing Education Perspectives. 2010; 31: 387-389. PMid:21280447

[34] Dhar S, Alfort R, Nelson E, et al. Enhancing exposure to genetics and genomics through an innovative medical school curriculum. Genetics in Medicine. 2012; 14(1): 163-167. PMid:22237446 http://dx.doi.org/10.1038/gim.0b013e31822dd7d4

[35] Roter D, Edelman E, Larson S, et al. Effects of online genetics education on physician assistant interviewing skills. Journal of American Academy of Physician Assistants. 2012; 25(2): 34-41. http://dx.doi.org/10.1097/01720610-201208000-00007 
[36] Howard V, Englert N, Kameg K, et al. Integration of simulation across the undergraduate curriculum: Student and faculty perspectives. Clinical Simulation in Nursing. 2011; 7: e1-e10. http: //dx.doi.org/10.1016/j.ecns.2009.10.004

[37] National League for Nurses (NLN). Simulation in Nursing Education Volume II Scenarios for SimMan. 2011. Available from: http://www.mysimcenter. com/product/simulation-in-n ursing-education-volume-ii-scenarios-for-simman-s ms2909. aspx

[38] Sharoff L. Simulation Preparation, Clinical Judgment and Reflective Process. What is the Connection? Journal of Contemporary Education. 2015; 5(2): 88-101.

[39] Sharoff L. Integrating YouTube into Nursing Curriculum, OJIN: The Online Journal of Issues in Nursing. 2011; 16(3). Available from: http://nursingworld.org/MainMenuCategories/AN AMarketplace/ANAPeriodicals/OJIN/TableofContents/V ol-16-2011/No3-Sept-2011/Articles-Previous-Topics / YouTube-and-Nursing-Curriculum.html PMid:22324572

[40] Cantrell M. The Importance of Debriefing in Clinical Simulations. Clinical Simulation in Nursing. 2008; 4(2): e19-e23. http://dx.d oi.org/10.1016/j.ecns.2008.06.006

[41] Jeffries P. A framework for designing, implementing, and evaluating simulations used as teaching strategies in nursing. Nursing Education Perspectives. 2005; 26(2): 96-103. PMid:15921126

[42] Foronda C, Liu S, Bauman E. Evaluation of Simulation in Undergraduate Nurse Education: An Integrative Review. Clinical Simulation in Nursing. 2013; 9(10): e409-e416. http://dx.doi.org/10.1016 /j.ecns. 2012.11.003

[43] Vural B, Tomatir A, Kurban N, et al. Nursing students' self-reported knowledge of genetics and genetic education. Public Health Genomics. 2009; 12: 225-232. PMid:19182476 http://dx.doi .org /10.1159/000197972

[44] Dodson C, Lewallen L. Nursing students' perceived knowledge and attitude towards genetics. Nurse Education Today. 2011; 31(4): $333-$ 339. PMid:20678829 http://dx.doi.org/10.1016/j.nedt. 20 10.07 .001
[45] Tanner CA. Thinking like a nurse: A research-based model of clinical judgment in nursing. Journal of Nursing Education. 2006; 45: 204-211. PMid:16780008

[46] Lasater K. Clinical Judgment Development: Using simulation to create an assessment rubric. Journal of Nursing Education. 2007; 47(11): 496-503.

[47] Benner P, Tanner C, Chesla C. Expertise in Nursing Practice: Caring, Clinical judgment, and ethics. (2nd ed.). NY: Springer Publishing; 2009.

[48] Badzek L, Henaghan M, Turner M, et al. Ethical, legal, and social issues in the translation of genomics into health care. Journal of Nursing Scholarship. 2013; 45(1): 15-24. PMid:23369261 http://dx.doi.org/10.1111/jnu. 12000

[49] Edwards Q, Maradiegue A, Seibert D, et al. Faculty members' perceptions of medical genetics and its integration into nurse practitioner curricula. Journal of Nursing Education. 2006; 45(3): 124-130. PMid:16562802

[50] Howard V, Englert N, Kameg K, et al. Integration of simulation across the undergraduate curriculum: Student and faculty perspectives. Clinical Simulation in Nursing. 2011; 7: e1-e10. http: //dx.doi.org/10.1016/j.ecns. 2009.10.004

[51] Johnson N, Giarelli E, Lewis C, et al. Genomics and autism spectrum disorder. Journal of Nursing Scholarship. 2013; 45(1): 6978. PMid:23368711 http://dx.doi.org/10.1111/j.1547-5 $069.2012 .01483 . \mathrm{x}$

[52] De Sevo M. Competency of nurse educators in genetics/genomics knowledge. Journal of Nursing Education and Practice. 2013; 3(1): 123-129. http://dx.doi.org/10.5430/jnep.v3n1p123

[53] International Society of Nurses in Genetics. (n.d.). Available from: http://isong.org/ISONG_genetic_nurse.php

[54] Daack-Hirsch S, Dieter C, Griffin M. Integrating genomics into undergraduate nursing education. Journal of Nursing Education. 2011; 43(3): 223-230. http://dx.doi.org/10.1111/j.1547-5069. $2011.01400 . \mathrm{x}$ 